Article

\title{
Quaternary-ammonium-immobilized polystyrenes as efficient and reusable heterogeneous catalysts for synthesis of cyclic carbonate: Effects of linking chains and pendent hydroxyl group
}

\author{
Xiaoming Yan a,b, Xuan Ding a, Yu Pan a, Xiaowei Xu a, Ce Hao a, Wenji Zheng a, Gaohong He a,b,* \\ a State Key Laboratory of Fine Chemicals, Research and Development Center of Membrane Science and Technology, School of Petroleum and Chemical \\ Engineering, Dalian University of Technology, Panjin 124221, Liaoning, China \\ b State Key Laboratory of Fine Chemicals, School of Chemical Engineering, Dalian University of Technology, Dalian 116024, Liaoning, China
}

\section{A R T I C L E I N F O}

\section{Article history:}

Received 14 February 2017

Accepted 16 March 2017

Published 5 May 2017

Keywords:

Cycloaddition

Ammonium

Long alkyl chain

Hydroxyl group

Heterogeneous catalyst

\begin{abstract}
A B S T R A C T
Spherical polystyrene-supported ammonium salts containing different linking chains between the support and ammonium groups were prepared as efficient and easily reusable heterogeneous catalysts for the cycloadditions of $\mathrm{CO}_{2}$ and epoxides. The effects of the length of the linking chains and a hydroxyl group pendent on the linking chain on the catalytic performance of ionic liquid immobilized catalysts and their mechanisms were studied through experiments and density functional theory calculations. It was found that, compared with a short linking chain, a long chain can make the halogen anion more negative and provide a larger contact area of the catalysts with the reactants, thus enhancing the reaction kinetics. The hydroxyl group can stretch the $\mathrm{C}-\mathrm{O}$ bonds of the epoxides, promoting the reaction thermodynamics. As a result, for the cycloaddition of propylene oxide, the yield of propylene carbonate is much higher for the catalyst with a long linking chain (yield: 91.4\%) compared with the yield for that with a short chain (yield: $70.9 \%$ ), and is further increased in the presence of pendent hydroxyl groups (yield: 98.5\%). The catalyst also shows a high catalytic activity even at mild temperature and good reusability (yield: $\geq 96 \%$ for 10 cycles), and the selectivity is always above $99 \%$.
\end{abstract}

(C) 2017, Dalian Institute of Chemical Physics, Chinese Academy of Sciences. Published by Elsevier B.V. All rights reserved.

\section{Introduction}

Carbon dioxide $\left(\mathrm{CO}_{2}\right)$ is a readily available renewable carbon resource that exhibits some advantages, including low cost, nontoxicity, and abundant reserves [1-9]. Recently, the fixation of $\mathrm{CO}_{2}$ to produce cyclic carbonates has attracted growing interest since cyclic carbonates play an important role in society $[10,11]$. Cyclic carbonates are widely used as polar solvents, electrolytes in lithium-ion batteries, precursors for polycar- bonate, and so forth $[12,13]$. However, the use of $\mathrm{CO}_{2}$ still faces a big challenge owing to its high thermodynamic stability and kinetic inertness [14]. Catalysts are considered to be essential to activate $\mathrm{CO}_{2}$ for cycloaddition $[15,16]$.

In the past few decades, a considerable number of homogeneous catalysts have been developed for the coupling of $\mathrm{CO}_{2}$ and epoxides. Various homogeneous catalysts, such as alkali metals [17,18], metal-salen complexes [19-22], and ionic liquids (ILs) [23-25], have been employed. Among them, ILs have

\footnotetext{
* Corresponding author. Tel/Fax: +86-411-84986219; E-mail: hgaohong@dlut.edu.cn

This work was supported by the National Natural Science Foundation of China (21406031, 21476044, U1663223), the Changjiang Scholars Program (T2012049), the State Key Laboratory of Fine Chemicals (KF1507), Dalian High-Level Talent Support Program (2015R056), Education Department of the Liaoning Province of China (LT2015007), and Fundamental Research Funds for the Central Universities (DUT16TD19). DOI: 10.1016/S1872-2067(17)62819-5 | http://www.sciencedirect.com/science/journal/18722067 | Chin. J. Catal., Vol. 38, No. 5, May 2017
} 
been widely studied owing to their outstanding properties of good thermal stability, negligible vapor pressure, and high tunability [26,27]. So far, ILs, including quaternary ammonium salts [28-30], imidazolium salts [31,32], and quaternary phosphonium salts [33-35], have been shown to exhibit high catalytic activities. In addition, ILs have been modified with the addition of various functional groups in their cations or anions to further increase the catalytic activity [36]. However, these homogeneous catalysts inevitably possess some problems, such as, the difficulty to recover the catalysts from products and also to purify the products.

The heterogeneous catalytic process has the potential to solve these problems through easy solid/liquid separations. ILs immobilized on polymer [32,37], silica [38,39], SBA-15 [40], graphene oxide [41,42], and carboxymethyl cellulose [43,44] supports have been widely developed as heterogeneous catalysts for the cycloaddition of $\mathrm{CO}_{2}$ and epoxides. These heterogeneous catalysts have exhibited great advantages, but the poor catalytic activity is still of concern, especially under mild reaction conditions. To solve this problem, the effect of the structures of catalytically-active groups on the performance of the catalyst has to be further studied.

Although a number of approaches have been used to introduce active groups onto the supports, no matter what the support is, a main difference for catalysts with the same active group is the length of the linking chain between the support and active groups $[45,46]$. To the best of our knowledge, there has never been a study on the impact of the linking chain length on the catalytic performance. In addition, having a strong hydrogen bond donating capacity, the hydroxyl group as an end group has demonstrated a synergistic effect on the cycloaddition reaction of epoxide and $\mathrm{CO}_{2}$ [47]. However, it is unknown if the hydroxyl group as a lateral group also exhibits the promotion effect.

In the present work, new spherical polystyrene-supported ammonium salts containing different linking chains between the support and ammonium group were prepared. The effect of the length of linking chains between the supports and ammonium groups was investigated. A polystyrene-supported ammonium with a hydroxyl group on the linking chain was also synthesized and the impact of a pendent hydroxyl group was studied. In addition, the charges of halogen anions in the different catalysts and the interaction of the hydroxyl group were studied by density functional theory (DFT) calculations. It was found that compared with a short linking chain, a long chain can provide a catalyst with a more negative halogen anion as well as a larger contact area of the catalysts with reactants, thus enhancing the reaction kinetics. The hydroxyl group can stretch the $\mathrm{C}-\mathrm{O}$ bonds of epoxides, which promotes the reaction thermodynamics. As a result, the yield is much higher for the catalyst with a long linking chain than for that with a short chain, and is further enhanced by the introduction of hydroxyl groups. The effect of the reaction conditions and the reusability of the catalyst were also studied.

\section{Experimental}

\subsection{Chemicals}

Spherical chloromethylated polystyrene resin (CMPS, 1 $\mathrm{mm}$ ) with $17 \% \mathrm{Cl}$ content and $7 \%$ cross-linked with divinylbenzene was purchased from the Chemical Plant of Nankai University. Propylene oxide was acquired from Sinopharm Chemical Reagent Co., Ltd. and was distilled before the reaction. Other epoxides and glycidyl trimethylammonium chloride were purchased from J\&K Chemical. 3-Bromopropylamine hydrobromide was purchased from Bide Pharmatech Ltd. Trimethylamine and ammonia aqueous solution were purchased from Shanghai Macklin Biochemical Co., Ltd. $\mathrm{CO}_{2}$ with a purity of $99.999 \%$ was commercially available. Sodium hydroxide and other chemical solvents were purchased from Tianjin Kemiou Chemical Reagent Co., Ltd. without any further purification.

\subsection{Characterization}

Nuclear magnetic resonance (NMR) spectra were obtained on a Bruker 500 AVANCE II spectrometer, using $\mathrm{CDCl}_{3}$ or DMSO-d 6 as solvent with a TMS reference. Fourier transformation infrared (FT-IR) spectra were recorded on a Nicolet iN10 spectrometer (Thermo Fisher). Scanning electron microscopic (SEM) patterns were collected with a NOVA NanoSEM 450 microscope. Energy dispersive X-ray spectroscopy (EDX) observations were performed by using an accessory (INCA 250) of the NOVA NanoSEM 450 instrument. Thermal gravimetric analysis (TGA) curves were obtained on a TGA/DSC1 instrument (Mettler Toledo) using a heating rate of $10^{\circ} \mathrm{C} / \mathrm{min}$ in a $\mathrm{N}_{2}$ flow.

\subsection{Catalyst preparation}

1-Amino-2-hydroxy-3-trimethylammonium propane chloride (AHTAPC) was synthesized according to the literature procedure (Scheme 1) [48]. First, glycidyl trimethylammonium chloride (25 mmol, $4 \mathrm{~g}$ ) was dissolved in deionized water (10 $\mathrm{mL}$ ) to form a solution, which was added dropwise to the 25 wt $\%$ ammonia aqueous solution $(300 \mathrm{~mL})$ with stirring. The reaction was kept at $40{ }^{\circ} \mathrm{C}$ for $12 \mathrm{~h}$. Then, the solvent and excess ammonia were removed at $50{ }^{\circ} \mathrm{C}$ under a vacuum environment to yield AHTAPC. ${ }^{1} \mathrm{H}$ NMR of AHTAPC $(500 \mathrm{MHz}$, TMS, $\left.\mathrm{CDCl}_{3}\right): \delta=2.75-2.79\left(\mathrm{~m}, \mathrm{CH}_{2}, 1 \mathrm{H}\right), 2.88-2.92\left(\mathrm{~m}, \mathrm{CH}_{2}, 1 \mathrm{H}\right), 3.46$ (s, $\left.\mathrm{CH}_{3}, 9 \mathrm{H}\right), 3.56-3.59\left(\mathrm{~m}, \mathrm{CH}_{2}, 1 \mathrm{H}\right), 3.81-3.84\left(\mathrm{~m}, \mathrm{CH}_{2}, 1 \mathrm{H}\right)$, 4.27-4.32 (m, CH, 1H).

3-Trimethylammonium propylamine bromide (TAPB) was synthesized according to the literature procedure (Scheme 2) [49]. A solution of 3-bromopropylamine hydrobromide (2.23 g, $10 \mathrm{mmol}$ ) in $10 \mathrm{~mL}$ of ethanol was added to a $30 \mathrm{wt} \%$ aqueous solution of trimethylamine $(5.9 \mathrm{~mL}, 30 \mathrm{mmol})$, and the reaction mixture was stirred at $25^{\circ} \mathrm{C}$ for $5 \mathrm{~d}$. Then, the ethanol and wa-

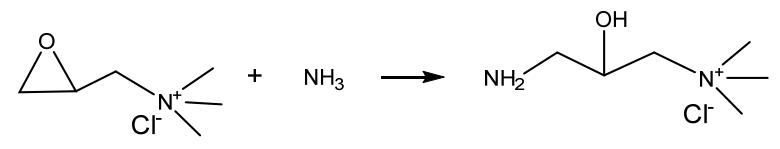

Scheme 1. Synthesis of 1-amino-2-hydroxy-3-trimethylammonium propane chloride (AHTAPC). 
<smiles>CN(C)[C@@H](C[N+](C)(C)CCCNNCC[N+](C)(C)CCCN)NCCCBr</smiles>

Scheme 2. Synthesis of 3-trimethylammonium propylamine bromide (TAPB).

ter were removed by distillation under reduced pressure to yield a white solid. Next, the solid was dissolved in isopropyl alcohol under $83{ }^{\circ} \mathrm{C}$, and the white crystals were precipitated by standing at $25{ }^{\circ} \mathrm{C}$ overnight. Then, a white solid was obtained by recrystallization twice in isopropyl alcohol, followed by washing with dichloromethane and drying. The solid was dissolved in a small amount of deionized water, and the $\mathrm{pH}$ of the system was adjusted to 9-10 with $0.1 \mathrm{~mol} / \mathrm{L} \mathrm{NaOH}$ solution. After that, most of the water was removed by distillation under reduced pressure, and the residue solid was again dissolved in a large amount of anhydrous ethanol and the mixture was centrifuged at $7000 \mathrm{r} / \mathrm{min}$ for $15 \mathrm{~min}$. Finally, the clear liquid was distilled by removing the ethanol to yield the TAPB. ${ }^{1} \mathrm{H}$ NMR of TAPB (500 MHz, TMS, DMSO-d 6 ): $\delta=1.74-1.79\left(\mathrm{~m}, \mathrm{CH}_{2}, 2 \mathrm{H}\right.$ ), 2.61-2.63 (t, $\left.\mathrm{CH}_{2}, 2 \mathrm{H}\right), 3.07$ (s, $\left.\mathrm{CH}_{3}, 9 \mathrm{H}\right), 3.36-3.39\left(\mathrm{~m}, \mathrm{CH}_{2}, 2 \mathrm{H}\right)$.

CMPS-supported catalyst ([AHTAPC-PS]Cl) was synthesized by the reaction of CMPS and AHTAPC. CMPS $(1 \mathrm{~g})$ was added in $30 \mathrm{~mL}$ DMSO, and $20 \mathrm{~mL} 5 \mathrm{wt} \%$ DMSO solution of AHTAPC was added into the reaction system and the mixture was stirred for $48 \mathrm{~h}$ at $100{ }^{\circ} \mathrm{C}$. The product was collected by filtration and washed ten times with diethyl ether and anhydrous ethanol, after drying at $65^{\circ} \mathrm{C}$ under vacuum for $12 \mathrm{~h}$. The resulting solid was denoted as [AHTAPC-PS]Cl. Then, the catalyst [AHTAPC-PS]Cl was immersed into saturated $\mathrm{KBr}$ solution at room temperature for $12 \mathrm{~h}$ to perform ion-exchange. The product was filtered and washed five times with deionized water and anhydrous ethanol, then dried at $65{ }^{\circ} \mathrm{C}$ under vacuum for $12 \mathrm{~h}$ to obtain the product [AHTAPC-PS]Br. For the synthesis of the catalyst [AHTAPC-PS]I, [AHTAPC-PS]Br was immersed into saturated $\mathrm{NaI}$ solution to perform ion-exchange in the dark under a nitrogen atmosphere. The catalyst [TAPB-PS]Br was synthesized by the reaction of CMPS and TAPB according to the above procedures. The catalyst [TMA-PS]Cl was synthesized by the reaction of CMPS and trimethylamine (TMA). CMPS ( $1 \mathrm{~g}$ ) was added in $20 \mathrm{~mL} 25 \mathrm{wt} \%$ TMA aqueous solution, and the mixture was stirred at $25^{\circ} \mathrm{C}$ for $48 \mathrm{~h}$ to obtain [TMA-PS]Cl. An ion-exchange procedure was also used to acquire [TMA-PS]Br. The synthesis process and chemical structures of [AHTAPC-PS]X, [TAPB-PS]Br, and [TMA-PS]X are shown in Scheme 3. FT-IR, SEM, and EDX were used to confirm the synthesis of long-chain functional quaternary-ammonium-immobilized polystyrene. The thermal stability of the catalyst was performed by TGA at a heating rate of 10 ${ }^{\circ} \mathrm{C} / \mathrm{min}$ with the temperature ranging from 25 to $600{ }^{\circ} \mathrm{C}$ in a $\mathrm{N}_{2}$ flow.

\subsection{IL grafting capacity}

The IL grafting capacity was defined to represent the content of the quaternary ammonium group in catalysts, and was determined by the back titration method. Specifically, $0.1 \mathrm{~g}$

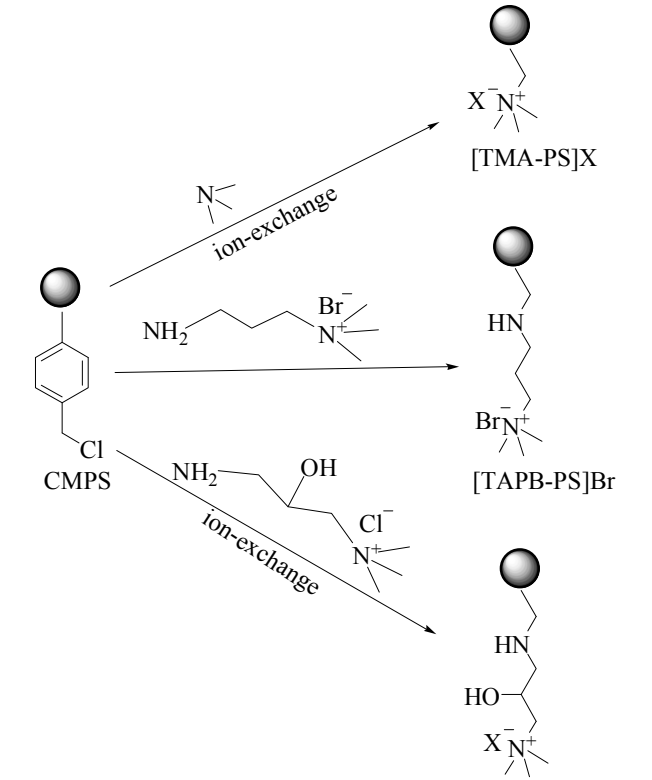

[AHTAPC-PS]X $(\mathrm{X}=\mathrm{Cl}, \mathrm{Br}, \mathrm{I})$

Scheme 3. Synthesis of [AHTAPC-PS]X, [TAPB-PS]Br, and [TMA-PS]X.

catalysts were immersed in the $\mathrm{NaOH}$ aqueous solution (1 $\mathrm{mol} / \mathrm{L}$ ) for $24 \mathrm{~h}$, followed by washing with deionized water to neutral. Then, $60 \mathrm{~mL} \mathrm{HCl}$ standard solution ( $0.01 \mathrm{~mol} / \mathrm{L})$ was added. After immersion for $24 \mathrm{~h}$, the solution was then titrated with a $\mathrm{NaOH}$ standard solution $(0.01 \mathrm{~mol} / \mathrm{L})$ to neutral with phenolphthalein as the indicator. Next, the catalysts were immersed into saturated $\mathrm{KBr}$ solution at room temperature for 12 $\mathrm{h}$ to perform ion-exchange. The dry catalysts in the form of $\mathrm{Br}^{-}$ were obtained by filtration, washing five times with deionized water, and vacuum-drying at $65^{\circ} \mathrm{C}$ for $12 \mathrm{~h}$. The weights of the dry catalysts were registered. The IL grafting capacities (mmol/g) of [AHTAPC-PS]Br, [TAPB-PS]Br, and [TMA-PS]Br were calculated using the following equation:

IL grafting capacity $=\left(V_{\mathrm{HCl}} C_{\mathrm{HCl}}-V_{\mathrm{NaOH}} C_{\mathrm{NaOH}}\right) / m_{\text {dry }}$

where $V_{\mathrm{HCl}}(\mathrm{mL})$ is the volume of the standard $\mathrm{HCl}$ aqueous solution, $V_{\mathrm{NaOH}}(\mathrm{mL})$ is the volume of the standard $\mathrm{NaOH}$ aqueous solution consumed in the titration, $C_{\mathrm{HCl}}$ and $C_{\mathrm{NaOH}}(\mathrm{mol} / \mathrm{L})$ are the mole concentrations of the standard $\mathrm{HCl}$ and $\mathrm{NaOH}$ aqueous solution, respectively, and $m_{\mathrm{dry}}(\mathrm{g}$ ) is the mass of the dry catalysts.

\subsection{General procedure for the cycloaddition reaction}

All the cycloaddition reactions were conducted in a $100 \mathrm{~mL}$ high-pressure stainless-steel vessel equipped with a magnetic stirrer. In a typical run, the catalyst $(0.78 \mathrm{~mol} \%$, calculated in accordance with the amount of ionic liquid) was charged into the reactor vessel. The reactor was pressurized with $\mathrm{CO}_{2}$ to 4 $\mathrm{MPa}$ and then the pressure was released. After repeating the above step four times, the epoxide $(28.6 \mathrm{mmol})$ was injected into the reactor. The reactor was fed with $\mathrm{CO}_{2}$ to a desired pressure and heated to a specified temperature. The reaction was kept for a designated period of time. Then, the reactor was cooled to $0^{\circ} \mathrm{C}$ and $\mathrm{CO}_{2}$ was ejected slowly. The organic product was separated from the mixture by filtration. All the products 
were identified on a gas chromatograph that was equipped with a flame ionization detector (FID) and a DB-wax capillary column $(30 \mathrm{~m} \times 0.25 \mathrm{~mm} \times 0.25 \mathrm{~mm})$.

\section{Results and discussion}

\subsection{Catalyst characterization}

The FT-IR differential spectra of [AHTAPC-PS]Br, [TAPB-PS]Br, and [TMA-PS]Br, obtained by subtracting the spectrum of CMPS, are shown in Fig. 1. Positive (above the base line) bands in the spectra represent functional groups that were removed, whereas negative bands represent groups that are evident in the sample [50]. Accordingly, the positive characteristic peak at $1265 \mathrm{~cm}^{-1}$ in the spectra for all three catalysts arose from the disappearance of the stretching vibration of $\mathrm{C}-\mathrm{H}$ in the $-\mathrm{CH}_{2} \mathrm{Cl}$ group. The negative peaks at $1475 \mathrm{~cm}^{-1}$ in Fig. 1(a) and (c) and at $1473 \mathrm{~cm}^{-1}$ in Fig. 1(b) were assigned to the stretching vibration of the $\mathrm{C}-\mathrm{H}$ of $\mathrm{CH}_{3}$ in the quaternary ammonium groups. The negative peak at $1688 \mathrm{~cm}^{-1}$ in Fig. 1(a) and (b) was associated with the $\mathrm{N}-\mathrm{H}$ bending and stretching frequencies. The negative peaks at 1100 and $3360 \mathrm{~cm}^{-1}$ in Fig. 1(a) were attributed to the stretching vibration of $\mathrm{O}-\mathrm{H}$ in hydroxyl groups. The negative peak at $3390 \mathrm{~cm}^{-1}$ in Fig. 1(b) was the stretching vibration of $\mathrm{N}-\mathrm{H}$ in amino groups. Owing to the existence of water, there were the negative peaks at 1620 and $3410 \mathrm{~cm}^{-1}$ in Fig. 1(c). Based on the obtained spectra, it was confirmed that [AHTAPC-PS]Br, [TAPB-PS]Br, and [TMA-PS]Br were successfully synthesized.

The morphology of the synthetic catalysts was observed by SEM. As shown in Fig. 2, all the surfaces of [AHTAPC-PS]Br, [TAPB-PS]Br, and [TMA-PS]Br were roughened by the grafting of quaternary ammonium. The main elements in the surfaces of [AHTAPC-PS]Cl, [AHTAPC-PS]Br, and [AHTAPC-PS]I were determined by EDX. To guarantee the veracity of the measurement, the test area of the catalysts was more than $100 \times 100$ $\mu \mathrm{m}^{2}$. As shown in Fig. 3(d), the existence of $\mathrm{Cl}$ indicates the successful introduction of quaternary ammonium. The peak for $\mathrm{Cl}$ vanishes and the new peaks for $\mathrm{Br}$ and I appear in Fig. 3(e) and (f), suggesting the complete ion-exchange.

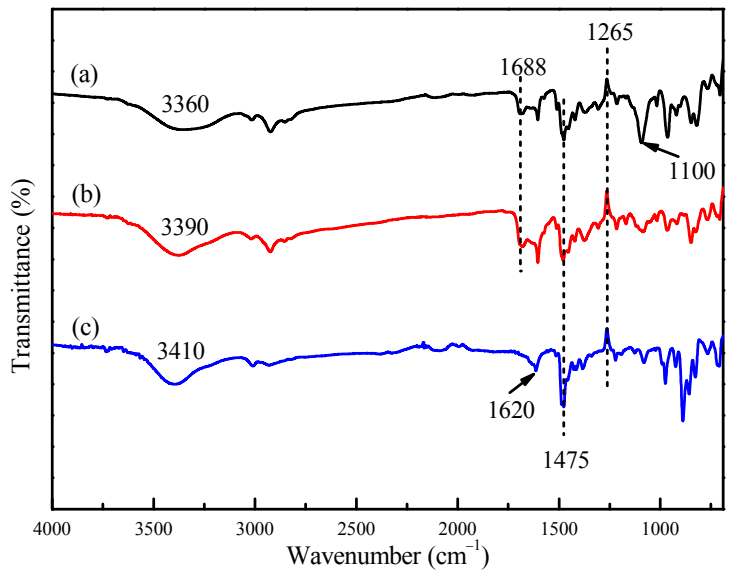

Fig. 1. The differential FT-IR spectra of [AHTAPC-PS]Br (a), [TAPB-PS]Br (b), and [TMA-PS]Br (c).

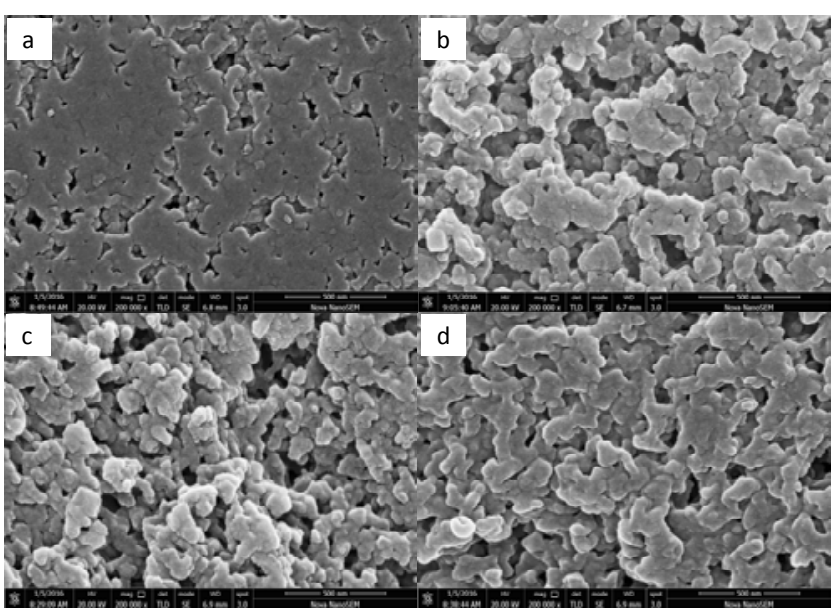

Fig. 2. SEM images of CMPS (a), [AHTAPC-PS]Br (b), [TAPB-PS]Br (c), and [TMA-PS]Br (d).

The TGA curves of [AHTAPC-PS]Br, [TAPB-PS]Br, and [TMA-PS]Br are presented in Fig. 4. The slight weight losses below $100{ }^{\circ} \mathrm{C}$ for all catalysts arose from the trace water absorbed by the catalysts. All five catalysts have two weight loss steps characterized by the onset decomposition temperature, $T_{\mathrm{OD}}$, and the fastest decomposition temperature, $T_{\mathrm{FD}}$. The first steps $\left(T_{\mathrm{OD}}=196,190,191,188\right.$, and $176{ }^{\circ} \mathrm{C}, T_{\mathrm{FD} 1}=236,230$, 232, 228, and $239{ }^{\circ} \mathrm{C}$ for [AHTAPC-PS]Br, [AHTAPC-PS]Cl, [AHTAPC-PS]I, [TAPB-PS]Br, and [TMA-PS]Br, respectively) were attributed to the cleavage of the grafted side chain ammoniums. The second steps were ascribed to the decomposition of the polystyrene chains. The thermal stabilities of all five catalysts were sufficiently high for their application in the cycloaddition reaction. The thermal stability for the catalysts with the anions of $\mathrm{Cl}, \mathrm{Br}$, and I exhibited no obvious difference.

\subsection{Catalytic performance}

Propylene oxide was chosen as a model substrate for the cycloaddition of $\mathrm{CO}_{2}$, and all catalyst screenings were performed using the same amounts of catalysts and propylene oxide. The results are summarized in Table 1 . All supported quaternary ammonium catalysts exhibit a high selectivity (above 99\%) for the synthesis of propylene carbonate (PC). Each catalyst was added at a loading of $0.78 \mathrm{~mol} \%$. [TMA-PS]Br resulted in a yield of $70.9 \%$. After the introduction of a long chain between the supporter polymer and ammonium group, [TAPB-PS]Br exhibited an enhanced activity (yield 91.4\%) compared with [TMA-PS]Br. The presence of the long chain between the supporter polymer and ammonium group increased the activity area of catalysts exposed to the mixture of $\mathrm{CO}_{2}$ and propylene oxide. The yield with [AHTAPC-PS]Br was up to 98.5\%, which was higher than that obtained with [TAPB-PS]Br. This suggests that the incorporation of the hydroxyl group onto the chain between supporter polymer and ammonium group could improve the catalytic activity. The catalytic activities of catalysts with different halide anions were also investigated. The activity order of the catalysts was $\mathrm{I}^{-}>\mathrm{Br}^{-}>>\mathrm{Cl}^{-}$, which is in accordance with the nucleophilicity order and leaving ability of the halides. 

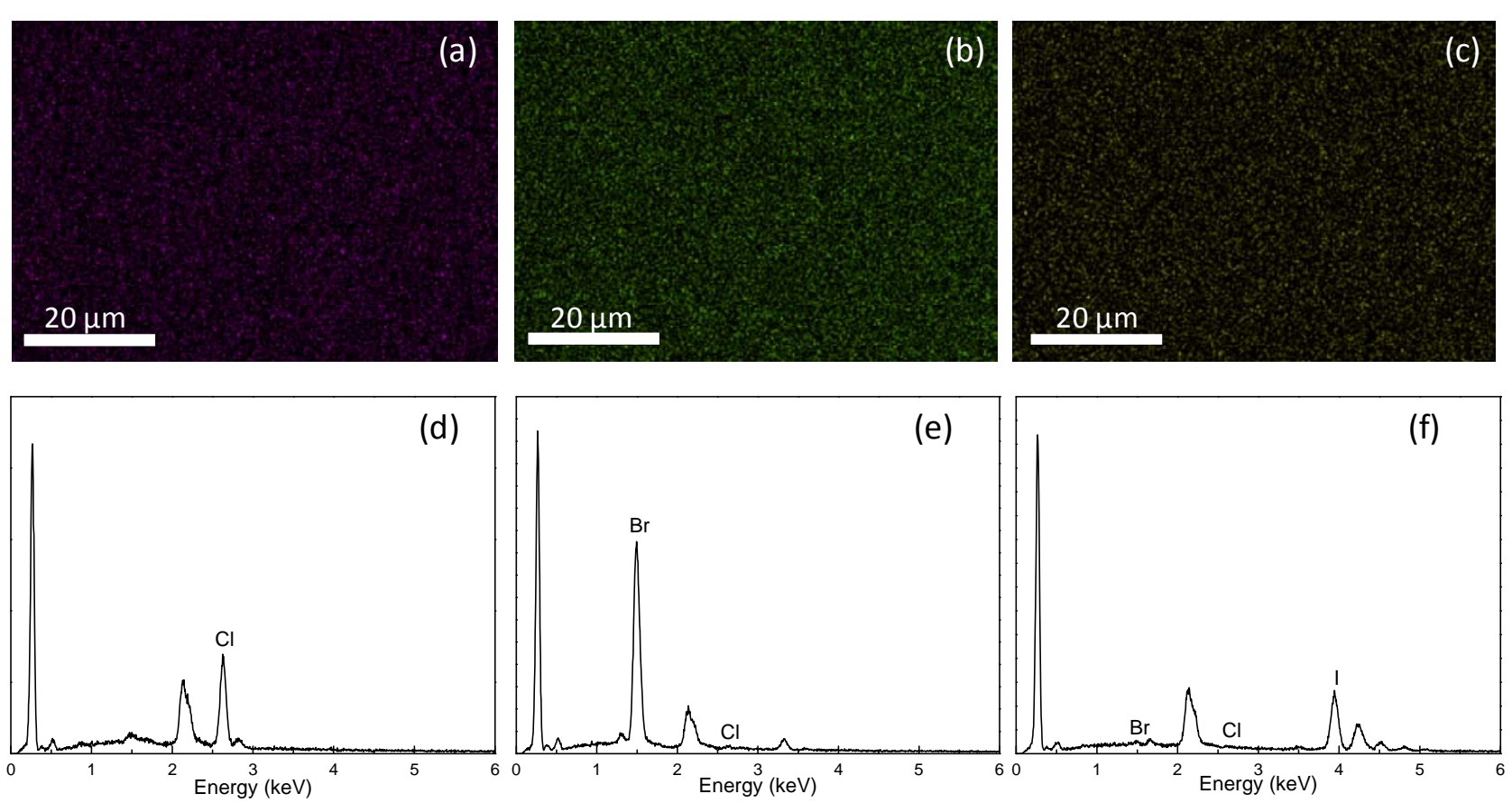

Fig. 3. EDX spectra for [AHTAPC-PS]Cl (a, d), [AHTAPC-PS]Br (b, e), and [AHTAPC-PS]I (c, f).

A stronger nucleophilicity results in an easier attack at the $\beta$-carbon atom of the epoxide, and the leaving ability in the ring-closing step is also important for the formation of the five-membered cyclic carbonate [51,52]. The $\mathrm{I}^{-}$and $\mathrm{Br}^{-}$forms of the catalysts show much higher activity than that of the $\mathrm{Cl}^{-}$ form. Considering the poor stability of $\mathrm{I}^{-}, \mathrm{Br}^{-}$is the best choice for this type of heterogeneous catalysts. As shown in Table 2, [AHTAPC-PS]Br exhibited the highest catalytic activity under mild conditions among the heterogeneous catalysts that have been reported in the literature.

To further investigate the effect of the long chain on the catalytic activity, the charge population analyses of catalysts were conducted using the DFT method (B3LYP, 6-311G ++(d, p)) [36]. As shown in Fig. 5, the electron density of $\mathrm{Br}^{-}$is slightly higher for [TAPB-PS]Br (Mulliken charge: -0.695) than for

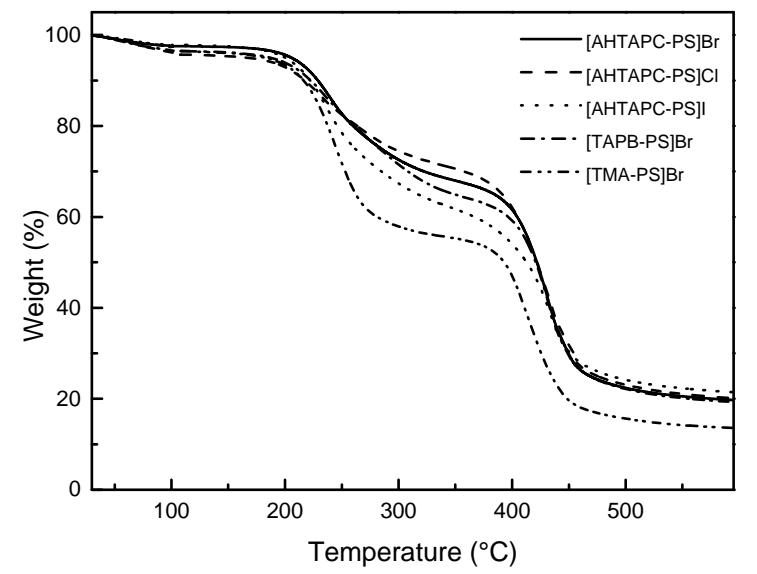

Fig. 4. TGA curves of [AHTAPC-PS]Br, [AHTAPC-PS]Cl, [AHTAPC-PS]I, [TAPB-PS]Br, and [TMA-PS]Br.
[TMA-PS]Br (Mulliken charge: -0.671). The $\mathrm{Br}^{-}$anion of [AHTAPC-PS]Br (Mulliken charge: -0.694) has almost the same electron density to that of [TAPB-PS]Br. This suggests that the introduction of a long chain increases the electron density, and weakens the electrostatic interaction between the anion and cation, which increases the mobility of the anion. Both the high electron density and mobility facilitate the nucleophilic attack of $\mathrm{Br}^{-}$at the $\beta$-carbon of the epoxide. Hence, the introduction of the long chain has two effects: one is to increase the catalytic activity area of catalysts; the other is to enhance the nucleophilic performance of anions. Both of these effects improve the catalytic activity of the catalysts. The influence of the hydroxyl group was also studied. As shown in Fig. 5, for PO and [AHTAPC-PS]Br, the strong hydrogen bond interaction between the hydrogen of the hydroxyl group and the oxygen of PO stretches the lengths of the C-O bonds from 1.4365/1.4345 to $1.4444 / 1.4404 \AA$, which would facilitate the breakage of the $\mathrm{C}-\mathrm{O}$ bond and thus increase the catalytic activity. Since the interaction between the hydrogen in - NH- and oxygen in $\mathrm{PO}$ is

Table 1

Catalytic performance of various catalysts.

\begin{tabular}{|c|c|c|c|c|}
\hline Entry & Catalyst & $\begin{array}{l}\text { Yield } \\
(\%)\end{array}$ & $\begin{array}{c}\text { Selectivity } \\
(\%)\end{array}$ & $\begin{array}{c}\text { IL grafting } \\
\text { capacity }(\mathrm{mmol} / \mathrm{g})\end{array}$ \\
\hline 1 & CMPS a & trace & trace & - \\
\hline 2 & [AHTAPC-PS]Br & 98.5 & 99.5 & 1.12 \\
\hline 3 & [TAPB-PS]Br & 91.4 & 99.6 & 1.01 \\
\hline 4 & [TMA-PS]Br & 70.9 & 99.8 & 1.27 \\
\hline 5 & [AHTAPC-PS]Cl b & 65.3 & 99.2 & 1.12 \\
\hline 6 & [AHTAPC-PS]Br b & 78.4 & 99.6 & - \\
\hline 7 & [AHTAPC-PS]I b & 81.4 & 99.7 & 1.12 \\
\hline
\end{tabular}

Reaction conditions: PO $28.6 \mathrm{mmol}$, catalyst $0.78 \mathrm{~mol} \%$, initial $\mathrm{CO}_{2}$ pressure $1.5 \mathrm{MPa}, 135^{\circ} \mathrm{C}, 3 \mathrm{~h}$.

${ }^{\mathrm{a}} \mathrm{CMPS} 0.1 \mathrm{~g}^{\mathrm{b}}{ }^{\circ} 100^{\circ} \mathrm{C}$. 
Table 2

Summary of data for cycloaddition reactions between $\mathrm{CO}_{2}$ and $\mathrm{PO}$.

\begin{tabular}{|c|c|c|c|}
\hline Reference & Catalyst & Reaction conditions & Yield (\%) \\
\hline Our work & [AHTAPC-PS]Br & PO $28.6 \mathrm{mmol}$, catalyst $0.78 \mathrm{~mol} \%, 1.5 \mathrm{MPa}, 100^{\circ} \mathrm{C}, 3 \mathrm{~h}$ & 78.4 \\
\hline Our work & [AHTAPC-PS]Br & PO $28.6 \mathrm{mmol}$, catalyst $0.78 \mathrm{~mol} \%, 0.4 \mathrm{MPa}, 100^{\circ} \mathrm{C}, 7 \mathrm{~h}$ & 70.9 \\
\hline Liu et al. [40] & $\mathrm{NH}_{3} \mathrm{I}-\mathrm{Zn} / \mathrm{SBA}-15$ & PO $2.0 \mathrm{~g}$, catalyst $0.1 \mathrm{~g}, 3 \mathrm{MPa}, 110^{\circ} \mathrm{C}, 12 \mathrm{~h}$ & 55 \\
\hline Watile et al. [32] & PS-DHPIMBr & PO $25 \mathrm{mmol}$, catalyst $0.2 \mathrm{~g}, 2 \mathrm{MPa}, 110^{\circ} \mathrm{C}, 3 \mathrm{~h}$ & 61 \\
\hline Aquino et al. [53] & ILCIM50/ZnBr2 & PO $100 \mathrm{mmol}$, catalyst $2.5 \mathrm{mmol}$, cocatalyst $0.625 \mathrm{mmol}, 4 \mathrm{MPa}, 110^{\circ} \mathrm{C}, 6 \mathrm{~h}$ & 67 \\
\hline Wu et al. [43] & $\mathrm{HBimCl}-\mathrm{NbCl}_{5} / \mathrm{HCMC}$ & PO $10 \mathrm{mmol}$, catalyst $0.1 \mathrm{~g}, 1.5 \mathrm{MPa}, 100^{\circ} \mathrm{C}, 3 \mathrm{~h}$ & 65 \\
\hline Sun et al. [47] & PS-HEIMBr & PO $0.1 \mathrm{~mol}$, catalyst $1.6 \mathrm{~mol} \%, 2.5 \mathrm{MPa}, 100^{\circ} \mathrm{C}, 4 \mathrm{~h}$ & 56 \\
\hline Sun et al. [54] & DBU-cellulose & P0 $1 \mathrm{~mL}, \mathrm{DBU} 225 \mathrm{mg}$, cellulose $15 \mathrm{mg}, 2.0 \mathrm{MPa}, 100^{\circ} \mathrm{C}, 2 \mathrm{~h}$ & 66 \\
\hline Song et al. [34] & t-BBPCl-fluoroacrylate polymer ${ }^{a}$ & PO $28.6 \mathrm{mmol}$, catalyst $1 \mathrm{~mol} \%, 8 \mathrm{MPa}, 120^{\circ} \mathrm{C}, 8 \mathrm{~h}$ & 58 \\
\hline Cheng et al. [55] & DBU/2-deoxy-D-ribose & PO $1 \mathrm{~mL}$, DBU $15 \mathrm{~mol} \%$, 2-deoxy-D-ribose $1 \mathrm{~mol} \%, 2 \mathrm{MPa}, 100^{\circ} \mathrm{C}, 2 \mathrm{~h}$ & $50 \mathrm{~b}$ \\
\hline
\end{tabular}

a Tributylbenzylphosphonium chloride ligated fluoroacrylate polymer. ${ }^{\mathrm{b}}$ Conversion (\%).

very weak and the -NH- group is far from the ammonium group, the promotion effect of the $-\mathrm{NH}$ - group could be ignored.

\subsection{Effects of reaction parameters}

The effects of the reaction parameters, including reaction temperature, $\mathrm{CO}_{2}$ pressure, and reaction time, on the [AHTAPC-PS]Br-based catalytic system were studied. The cycloaddition of $\mathrm{PO}$ and $\mathrm{CO}_{2}$ is expected to be conducted at moderate temperature with low energy consumption. Fig. 6(a) shows that the reaction temperature has a substantial effect on this reaction. The PC yield increased from $55.8 \%$ to $97.4 \%$ by increasing the temperature from 90 to $130{ }^{\circ} \mathrm{C}$. Once the reaction temperature was higher than $135^{\circ} \mathrm{C}$, the PC yield was always more than $98 \%$. The relationship between temperature

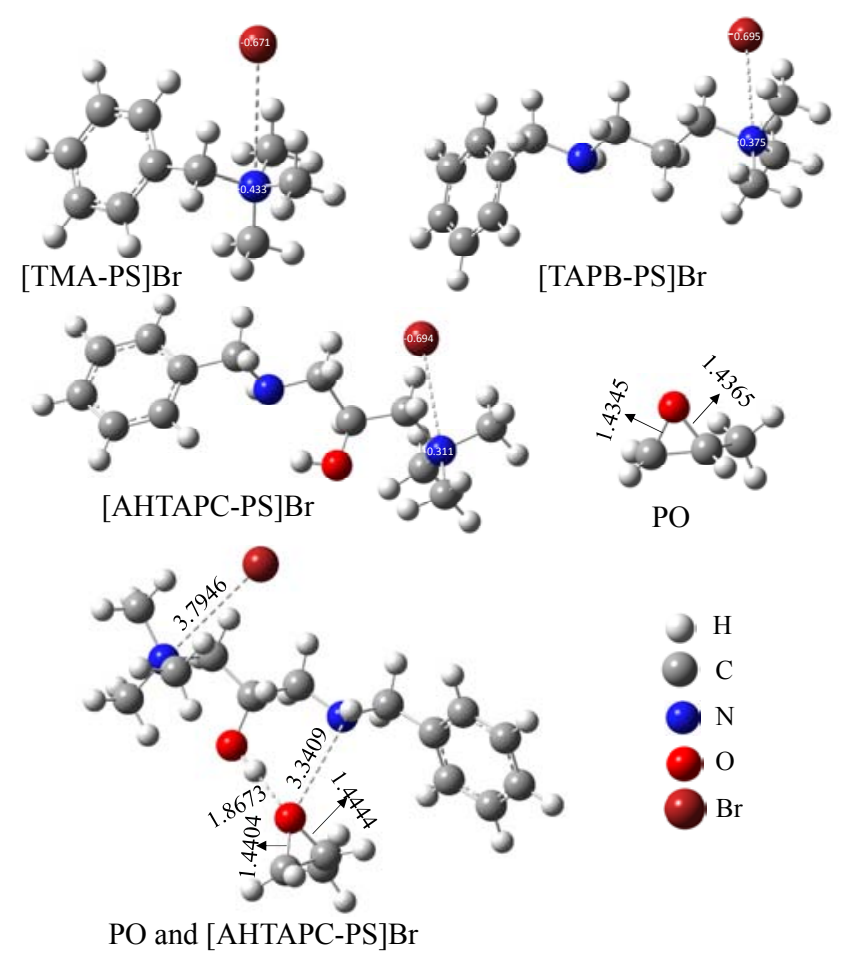

Fig. 5. Mulliken charge and intermolecular interaction of the catalysts. and yield was attributed to the higher reactivity at higher temperature. When the temperature was higher than $135^{\circ} \mathrm{C}$, the yield of PC remained constant, indicating that the reaction reached a thermodynamic equilibrium. It was observed that the high yield could be achieved at mild temperatures, for example, the yield was $78.4 \%$ at $100{ }^{\circ} \mathrm{C}$. The selectivity remained above $99 \%$ when the temperature was increased from 90 to $140{ }^{\circ} \mathrm{C}$. The structure of the catalyst is usually responsible for the selectivity $[37,56]$. This suggests that the [AHTAPC-PS]Br exhibits an essentially good catalytic selectivity for the cycloaddition of $\mathrm{PO}$ and $\mathrm{CO}_{2}$.

The effect of the $\mathrm{CO}_{2}$ pressure on the PC yield of the cycloaddition reaction at 100 and $135^{\circ} \mathrm{C}$ was studied. As shown in Fig. $6(\mathrm{~b})$, at $135^{\circ} \mathrm{C}$, the PC yield increased dramatically with increasing the $\mathrm{CO}_{2}$ pressure from 0.4 to $1.0 \mathrm{MPa}$. The yield was slightly increased at pressures from 1.0 to $1.5 \mathrm{MPa}$. The yield decreased to $93.9 \%$ at pressures $>1.5 \mathrm{MPa}$. Therefore, an appropriate $\mathrm{CO}_{2}$ pressure is required for an efficient cycloaddition reaction. An elevated pressure is favorable for the cycloaddition reaction, but too high a $\mathrm{CO}_{2}$ pressure might isolate the catalyst from $\mathrm{PO}$, resulting in a reduced yield. The competitive effect of these two factors resulted in the first increase and then decrease in the yield of PC. In addition, the $\mathrm{CO}_{2}$ pressure has almost no effect on the selectivity.

The dependence of the PC yield and selectivity on the reaction time are shown in Fig. 6(c). For the first hour, an obvious increase in the yield was observed, and the yield increased slowly to $98.5 \%$ over the next $2 \mathrm{~h}$. After $3 \mathrm{~h}$, the yield remained constant, indicating a reaction balance occurred after $3 \mathrm{~h}$. It was observed that the PC selectivity was always above $99.0 \%$.

The reaction temperature and pressure are important parameters to evaluate the activity of the catalyst. Mild reaction conditions would be attractive for industrial use. The above results suggest that the [AHTAPC-PS]Br catalyst possesses a good activity at mild temperature. Therefore, the effects of reaction time and $\mathrm{CO}_{2}$ pressure on the yield at $100{ }^{\circ} \mathrm{C}$ were investigated. As shown in Fig. 6(d), the yield increased at $<1.5 \mathrm{MPa}$ and decreased at $>1.5 \mathrm{MPa}$. The maximum yield was $78.4 \%$ at $1.5 \mathrm{MPa}$. It is noticed that the [AHTAPC-PS] Br exhibited a good activity at low pressure. Under a $\mathrm{CO}_{2}$ initial pressure of $0.4 \mathrm{MPa}$, the yield increased with reaction time and reached $78.8 \%$ after $10 \mathrm{~h}$, as shown in Fig. 6(e). The PC selectivity was above 99\% under all reaction conditions. 

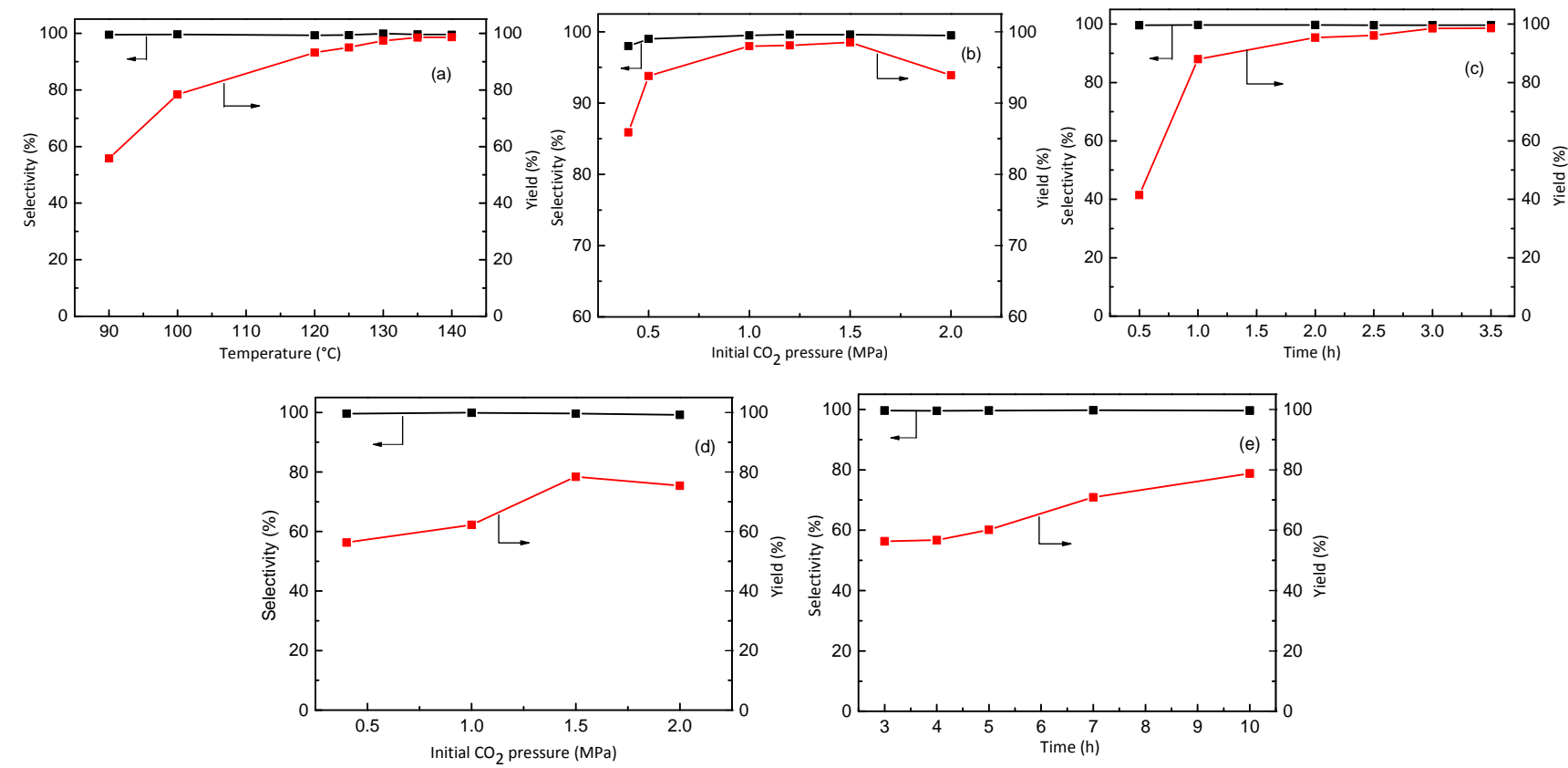

Fig. 6. Dependence of PC yield and selectivity on different parameters catalyzed by [AHTAPC-PS]Br catalyst. (a) Effect of reaction temperature (PO $28.6 \mathrm{mmol}$, catalyst $0.78 \mathrm{~mol} \%, 1.5 \mathrm{MPa}, 3 \mathrm{~h}$ ); (b) Effect of reaction pressure (PO $28.6 \mathrm{mmol}$, catalyst $0.78 \mathrm{~mol} \%, 135{ }^{\circ} \mathrm{C}, 3 \mathrm{~h}$ ); (c) Effect of reaction time (PO $28.6 \mathrm{mmol}$, catalyst $0.78 \mathrm{~mol} \%, 135^{\circ} \mathrm{C}, 1.5 \mathrm{MPa}$ ); (d) Effect of reaction pressure under mild condition (PO $28.6 \mathrm{mmol}$, catalyst $0.78 \mathrm{~mol} \%$, $100^{\circ} \mathrm{C}, 3 \mathrm{~h}$ ); (e) Effect of reaction time under mild condition (PO $28.6 \mathrm{mmol}$, catalyst $0.78 \mathrm{~mol} \%, 100{ }^{\circ} \mathrm{C}, 0.4 \mathrm{MPa}$ ).

\subsection{Catalyst recovery}

The recyclability of the [AHTAPC-PS]Br catalyst was examined with $\mathrm{PO}$ under an initial $\mathrm{CO}_{2}$ pressure of $1.5 \mathrm{MPa}$ at $135^{\circ} \mathrm{C}$ for $3 \mathrm{~h}$ ). In each run, the catalyst was recovered by filtration. As shown in Fig. 7, the catalyst exhibited a high activity across ten consecutive cycles. The PC yield remained constant for the first six recycles and was up to $96 \%$ after ten cycles. The selectivity always remained above 99\%. These results indicate that [AHTAPC-PS]Br exhibits good stability and is promising for commercial application in the continuous heterogeneous cycloaddition reaction. As shown in Fig. 8, there was no obvious

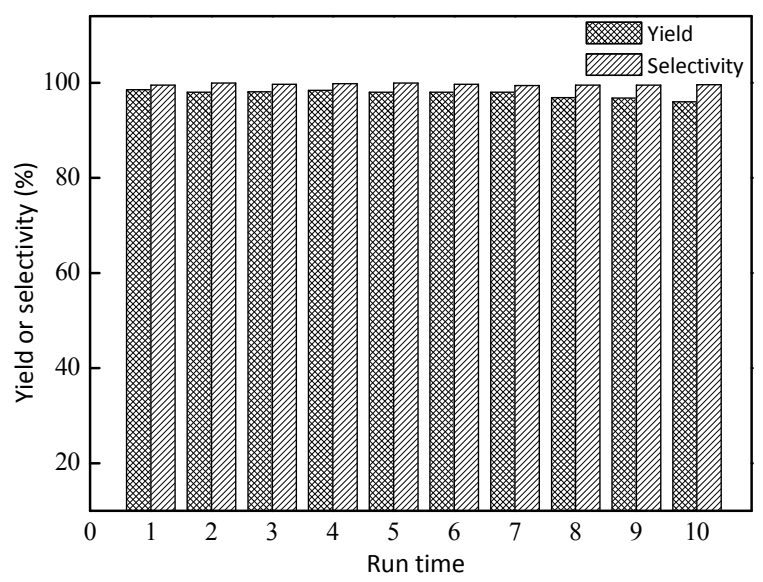

Fig. 7. Recyclability of the [AHTAPC-PS]Br catalyst. Reaction conditions: PO $28.6 \mathrm{mmol}$, catalyst $0.78 \mathrm{~mol} \%, 135^{\circ} \mathrm{C}, 3 \mathrm{~h}, 1.5 \mathrm{MPa}$. change on the differential spectra of FT-IR for the catalyst with a long linking chain [AHTAPC-PS]Br after ten runs. This indicates that [AHTAPC-PS]Br exhibited a good stability.

\subsection{Catalytic activity towards different epoxides}

The performances of the [AHTAPC-PS]Br catalyst were further studied for the cycloaddition of $\mathrm{CO}_{2}$ with various epoxides and the results are listed in Table 3 . All the reactions were carried out at $135{ }^{\circ} \mathrm{C}$ without any solvent. The [AHTAPC-PS]Br catalyst exhibited catalytic activities for all the selected epoxides. All the reactions showed a high selectivity (above 90\%). The yield of epichlorohydrin was lower than those of PO and

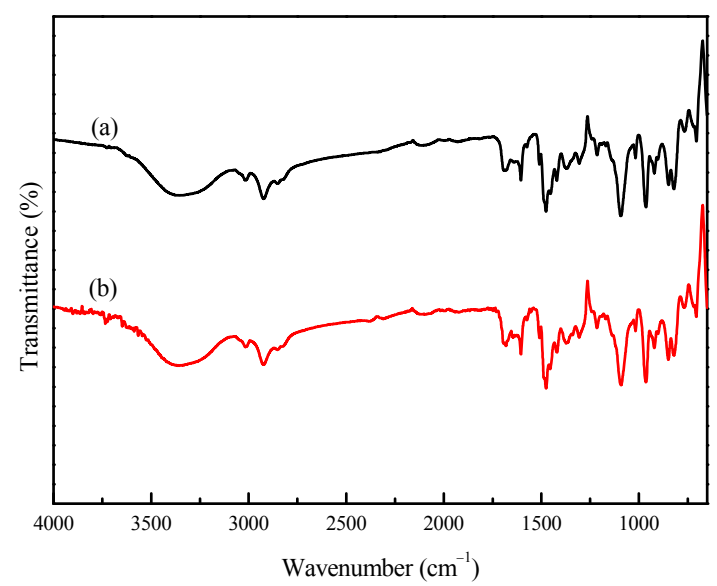

Fig. 8. FT-IR differential spectra of fresh catalyst (a) and used catalyst for 10 times (b). 
Table 3

Cycloaddition of $\mathrm{CO}_{2}$ with different epoxides catalyzed by [AHTAPC-PS]Br.

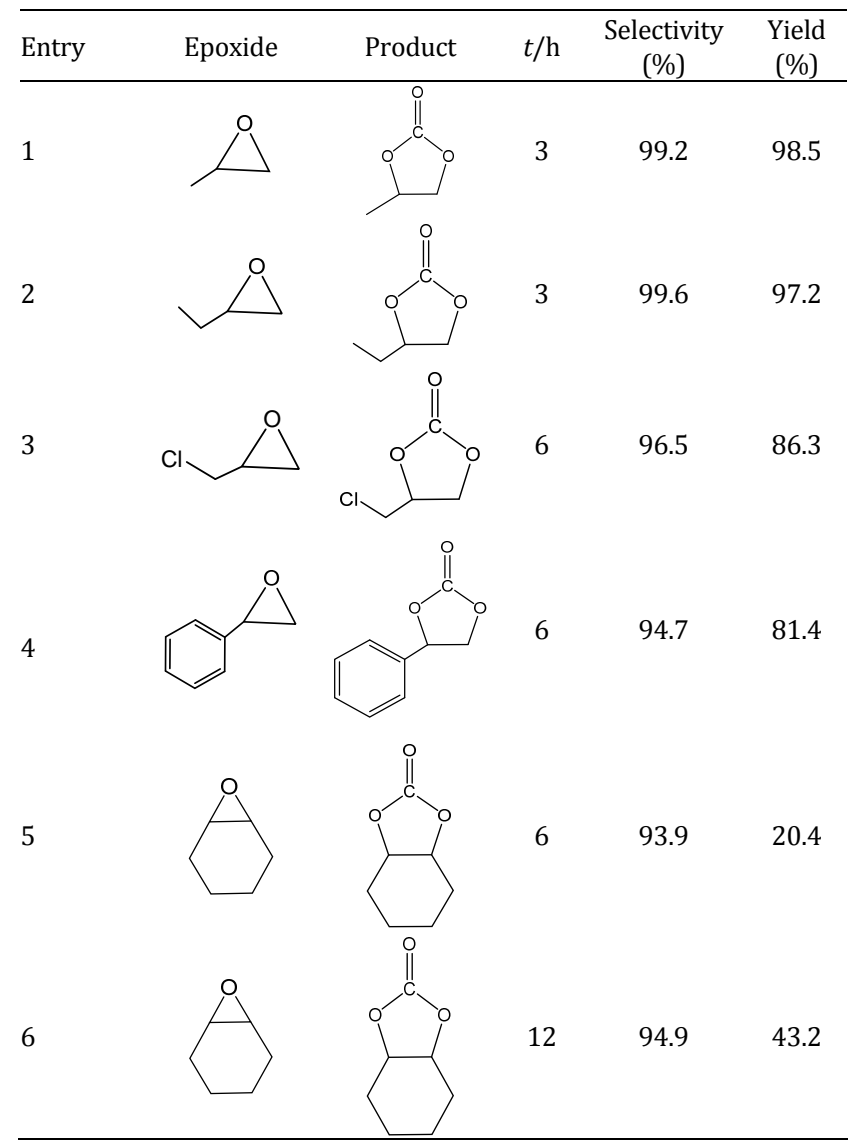

Reaction conditions: PO $28.6 \mathrm{mmol}$, catalyst $0.78 \mathrm{~mol} \%, 135^{\circ} \mathrm{C}, 3 \mathrm{~h}, 1.5$ $\mathrm{MPa}$.

1,2-epoxybutane owing to the electron withdrawing effect of the chloride. The cycloaddition of styrene oxide also exhibited a reduced reaction rate because of the large steric hindrance of the benzene ring and was even worse for cyclohexene owing to the large steric hindrances of both $\alpha$ - and $\beta$-carbons.

\subsection{Possible reaction mechanism}

As shown in Table 1, the order of the catalytic activity for [AHTAPC-PS]X is the same to that of the nucleophilicity of the halogen anion, suggesting that the nucleophilic attack of the halogen anion on the epoxide group is important for the cycloaddition reaction. In addition, the catalyst [AHTAPC-PS]Br with a hydroxyl group showed a better catalytic activity compared with [TAPB-PS]Br without an hydroxyl group. This indicates that although the hydroxyl group was located in the middle rather than at the end of the chain, the presence of a hydroxyl group is favorable for the cycloaddition reaction. As shown in Fig. 5, the length of the $\mathrm{C}-\mathrm{O}$ bonds was elongated from $1.4365 / 1.4345$ to $1.4444 / 1.4404 \AA$ owing to the stretching of the strong hydrogen bond interaction between the hydrogen in the hydroxyl group and oxygen in PO, which would facilitate the breakage of the $\mathrm{C}-\mathrm{O}$ bond. Based on the current

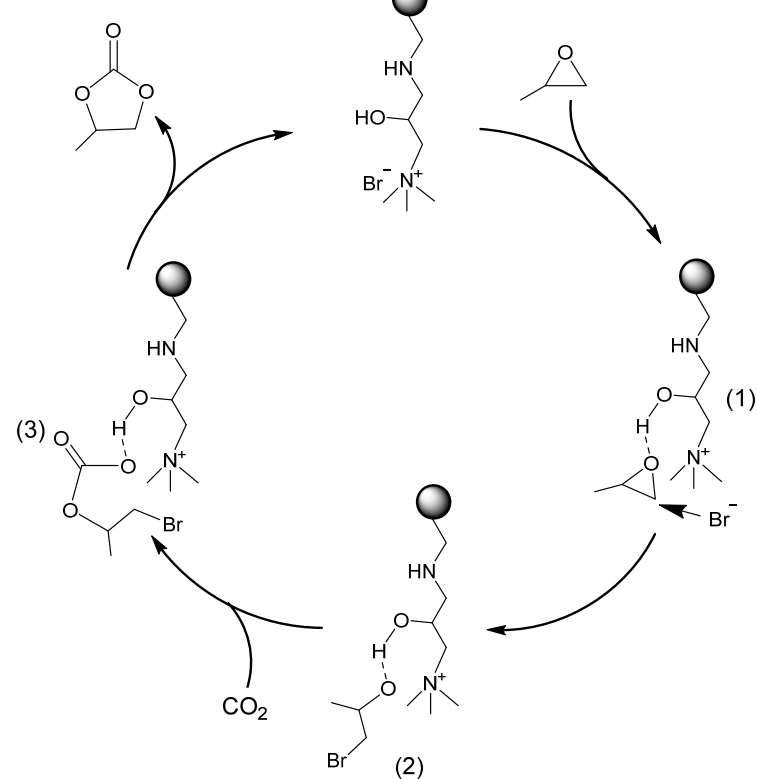

Scheme 4. Proposed mechanism for the cycloaddition reaction.

results and previous work $[3,4,26,57,58]$, a possible mechanism was proposed, as shown in Scheme 4. The hydrogen bond between the $\mathrm{H}$ atom in the $-\mathrm{OH}$ group of the catalyst and $\mathrm{O}$ atom in the epoxide stretched the $\mathrm{C}-\mathrm{O}$ bonds and also increased the polarization of the $\mathrm{C}-\mathrm{O}$ bonds, which activated the $\mathrm{PO}$ for ring-opening. At the same time, the $\mathrm{Br}^{-}$anion attacked the $\beta$-carbon of PO where the steric hindrance was minimal. The negative charge was shifted to the $\mathrm{O}$ atom of $\mathrm{PO}$ and then attacked the $\mathrm{C}$ atom of $\mathrm{CO}_{2}$ to form a $\mathrm{C}-\mathrm{O}$ bond because of the acidity of $\mathrm{CO}_{2}$. Finally, propylene carbonate was produced by the intramolecular substitution of the halide anion.

\section{Conclusions}

Spherical polystyrene-supported ammonium salts containing different linking chains between the support and ammonium group were prepared as efficient and easily reusable heterogeneous catalysts for the cycloadditions of $\mathrm{CO}_{2}$ and epoxides. The results from experiments and DFT calculations indicated that compared with a short linking chain, a long chain could make the halogen anion more negative and provide a larger contact area for the catalysts with the reactants, thus enhancing the reaction kinetics. The hydroxyl group could stretch the $\mathrm{C}-\mathrm{O}$ bonds of epoxides, providing more favorable reaction thermodynamics. As a result, for the cycloaddition of propylene oxide, the yield of propylene carbonate was much higher for the catalyst with a long linking chain (yield: 91.4\%) compared with that for a short chain (yield: 70.9\%), and was further increased in the presence of pendent hydroxyl groups (yield: 98.5\%). The selectivity was always above 99\%. The catalyst also showed high catalytic activity at mild temperature. In addition, the catalyst exhibited a good reusability (yield $\geq 96 \%$ for 10 cycles). Hence, the catalysts prepared here are promising for the large-scale production of cyclic carbonates. 


\section{Graphical Abstract}

Chin. J. Catal., 2017, 38: 862-871 doi: 10.1016/S1872-2067(17)62819-5

Quaternary-ammonium-immobilized polystyrenes as efficient and reusable heterogeneous catalysts for synthesis of cyclic carbonate: Effects of linking chains and pendent hydroxyl group

Xiaoming Yan, Xuan Ding, Yu Pan, Xiaowei Xu, Ce Hao, Wenji Zheng, Gaohong He * Dalian University of Technology

A polystyrene-supported ammonium catalyst provides larger contact area of catalysts with reactants, which enhances the reaction kinetics. A hydroxyl group on the linking chain stretches the $\mathrm{C}-\mathrm{O}$ bonds of epoxides, improving the reaction thermodynamics.

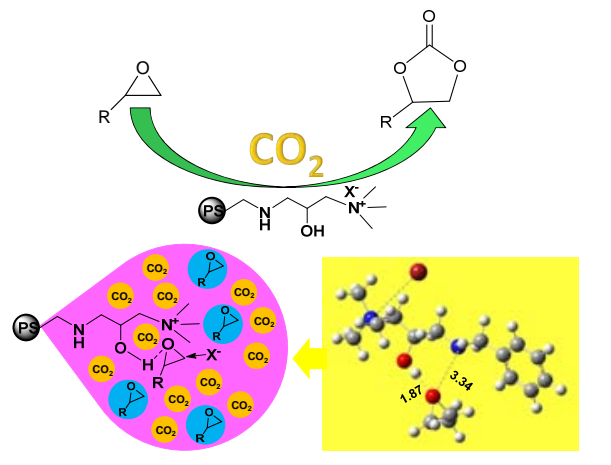

\section{References}

[1] M. North, R. Pasquale, C. Young, Green Chem., 2010, 12, 1514-1539.

[2] D. H. Lan, H. T. Wang, L. Chen, C. T. Au, S. F. Yin, Carbon, 2016, 100, 81-89.

[3] C. Y. Li, W. L. Wang, L. Yan, Y. Q. Wang, M. Jiang, Y. J. Ding, J. Mater. Chem. A, 2016, 4, 16017-16027.

[4] D. H. Lan, N. Fan, Y. Wang, X. Gao, P. Zhang, L. Chen, C. T. Au, S. F. Yin, Chin. J. Catal., 2016, 37, 826-845.

[5] D. F. Niu, Z. J. Wu, L. P. Zhang, R. B. Du, H. Xu, X. S. Zhang, Chin. J. Catal., 2016, 37, 1076-1080.

[6] S. Zhang, X. D. Li, L. N. He, Acta Chim. Sin., 2016, 74, 17-23.

[7] L. Liu, N. Tian, L. Huang, Y. H. Hong, A. Y. Xie, F. Y. Zhang, C. Xiao, Z. Y. Zhou, S. G. Sun, Chin. J. Catal., 2016, 37, 1070-1075.

[8] C. H. Liu, X. M. Guo, C. L. Zhong, L. Li, Y. X. Hua, D. S. Mao, G. Z. Lu, Chin. J. Inorg. Chem., 2016, 32, 1405-1412.

[9] F. Sha, B. Guo, F. Zhang, T. X. Zhao, Q. Li, J. B. Zhang, Chin. J. Inorg. Chem., 2016, 32, 1207-1214.

[10] C. J. Whiteoak, N. Kielland, V. Laserna, E. C. Escudero-Adan, E. Martin, A. W. Kleij, J. Am. Chem. Soc., 2013, 135, 1228-1231.

[11] J. Peng, H. J. Yang, Y. C. Geng, Z. D. Wei, L. H. Wang, C. Y. Guo, J. $\mathrm{CO}_{2}$ Util., 2017, 17, 243-255.

[12] V. Laserna, G. Fiorani, C. J. Whiteoak, E. Martin, E. Escudero-Adan, A. W. Kleij, Angew. Chem. Int. Ed., 2014, 53, 10416-10419.

[13] T. Cao, L. T. Sun, Y. Shi, L. Hua, R. Zhang, L. Guo, W. W. Zhu, Z. S. Hou, Chin. J. Catal., 2012, 33, 416-424.

[14] Y. S. Fu, Y. N. Li, X. Zhang, Y. Y. Liu, X. D. Zhou, J. L. Qiao, Chin. J. Catal., 2016, 37, 1081-1088.

[15] C. Maeda, Y. Miyazaki, T. Ema, Catal. Sci. Technol., 2014, 4, 1482-1497.

[16] X. B. Lu, D. J. Darensbourg, Chem. Soc. Rev., 2012, 41, 1462-1484.

[17] V. Calo, A. Nacci, A. Monopoli, A. Fanizzi, Org. Lett., 2002, 4, 2561-2563.

[18] H. P. Yang, L. X. Wu, H. Wang, J. X. Lu, Chin. J. Catal., 2016, 37, 994-998.

[19] D. Alhashmialameer, J. Collins, K. Hattenhauer, F. M. Kerton, Catal. Sci. Technol., 2016, 6, 5364-5373.

[20] S. Verma, R. I. Kureshy, T. Roy, M. Kumar, A. Das, N. u. H. Khan, S. H. R. Abdi, H. C. Bajaj, Catal. Commun., 2015, 61, 78-82.

[21] P. Ramidi, S. Z. Sullivan, Y. Gartia, P. Munshi, W. O. Griffin, J. A. Darsey, A. Biswas, A. U. Shaikh, A. Ghosh, Ind. Eng. Chem. Res., 2011, 50, 7800-7807.

[22] J. P. Chen, X. F. Du, T. J. Yu, Y. Zeng, X. H. Zhang, Y. Li, Acta Chim. Sin.,
2016, 74, 523-528.

[23] Q. He, J. W. O'Brien, K. A. Kitselman, L. E. Tompkins, G. C. T. Curtis, F. M. Kerton, Catal. Sci. Technol., 2014, 4, 1513-1528.

[24] G. D. Zhao, Y. Zhang, H. Y. Zhang, J. Li, S. Gao, J. Energy Chem., 2015 24, 353-358.

[25] F. F. Chen, Y. Dong, X. Y. Sang, Y. Zhou, D. J. Tao, Acta Phys. Chim. Sin., 2016, 32, 605-610.

[26] H. B. Xie, S. B. Zhang, S. H. Li, Green Chem., 2006, 8, 630-633.

[27] H. B. Xie, S. H. Li, S. B. Zhang, J. Mol. Catal. A, 2006, 250, 30-34.

[28] Q. Y. Deng, G. H. He, Y. Pan, X. H. Ruan, W. J. Zheng, X. M. Yan, RSC Adv., 2016, 6, 2217-2224.

[29] K. Motokura, S. Itagaki, Y. Iwasawa, A. Miyaji, T. Baba, Green Chem., 2009, 11, 1876-1880.

[30] A. J. R. Amaral, J. F. J. Coelho, A. C. Serra, Tetrahedron Lett., 2013, 54, 5518-5522.

[31] W. G. Cheng, X. Chen, J. Sun, J. Q. Wang, S. J. Zhang, Catal. Today, 2013, 200, 117-124.

[32] R. A. Watile, K. M. Deshmukh, K. P. Dhake, B. M. Bhanage, Catal. Sci. Technol., 2012, 2, 1051-1055.

[33] W. L. Wang, C. Y. Li, L. Yan, Y. Q. Wang, M. Jiang, Y. J. Ding, ACS Catal., 2016, 6, 6091-6100.

[34] Q. W. Song, L. N. He, J. Q. Wang, H. Yasuda, T. Sakakura, Green Chem., 2013, 15, 110-115.

[35] J. X. Chen, B. Jin, W. L. Dai, S. L. Deng, L. R. Cao, Z. J. Cao, S. L. Luo, X. B. Luo, X. M. Tu, C. T. Au, Appl. Catal. A, 2014, 484, 26-32.

[36] W. Zhang, Q. X. Wang, H. H. Wu, P. Wu, M. Y. He, Green Chem., 2014, 16, 4767-4774.

[37] Y. Y. Zhang, S. F. Yin, S. L. Luo, C. T. Au, Ind. Eng. Chem. Res., 2012, 51, 3951-3957.

[38] L. F. Xiao, F. W. Li, J. J. Peng, C. G. Xia, J. Mol. Catal. A, 2006, 253, 265-269.

[39] Z. L. Liu, Y. Teng, K. Zhang, H. G. Chen, Y. P. Yang, J. Energy Chem., 2015, 24, 322-330.

[40] M. S. Liu, B. Liu, L. Liang, F. X. Wang, L. Shi, J. M. Sun, J. Mol. Catal. A, 2016, 418, 78-85.

[41] J. Xu, M. Xu, J. Wu, H. Wu, W. H. Zhang, Y. X. Li, RSC Adv., 2015, 5, 72361-72368.

[42] W. H. Zhang, P. P. He, S. Wu, J. Xu, Y. X. Li, G. Zhang, X. Y. Wei, Appl. Catal. A, 2016, 509, 111-117.

[43] X. H. Wu, M. P. Wang, Y. Z. Xie, C. Chen, K. Li, M. M. Yuan, X. G. Zhao, Z. S. Hou, Appl. Catal. A, 2016, 519, 146-154.

[44] K. R. Roshan, G. Mathai, J. Kim, J. Tharun, G. A. Park, D. W. Park, Green Chem., 2012, 14, 2933-2940.

[45] S. M. Sadeghzadeh, Green Chem., 2015, 17, 3059-3066.

[46] A. H. Jadhav, G. M. Thorat, K. Lee, A. C. Lim, H. Kang, J. G. Seo, Catal. 
Today, 2016, 265, 56-67.

[47] J. Sun, W. G. Cheng, W. Fan, Y. H. Wang, Z. Y. Meng, S. J. Zhang, Catal. Today, 2009, 148, 361-367.

[48] J. J. Han, Q. Liu, X. Q. Li, J. Pan, L. Wei, Y. Wu, H. Q. Peng, Y. Wang, G. W. Li, C. Chen, L. Xiao, J. T. Lu, L. Zhuang, ACS Appl. Mater. Interfaces, 2015, 7, 2809-2816.

[49] X. M. Yan, L. Gao, W. J. Zheng, X. H. Ruan, C. M. Zhang, X. M. Wu, G. H. He, Int. J. Hydrogen Energy, 2016, 41, 14982-14990.

[50] P. C. Painter, R. W. Snyder, M. Starsinic, M. M. Coleman, D. W. Kuehn, A. Davis, Appl. Spectrosc., 1981, 35, 475-485.

[51] F. Castro-Gomez, G. Salassa, A. W. Kleij, C. Bo, Chem. Eur. J., 2013, 19, 6289-6298.

[52] H. Sun, D. J. Zhang, J. Phys. Chem. A, 2007, 111, 8036-8043.
[53] A. S. Aquino, F. L. Bernard, J. V. Borges, L. Mafra, F. D. Vecchia, M. O. Vieira, R. Ligabue, M. Seferin, V.V. Chaban, E.J. Cabrita, S. Einloft, RSC Adv., 2015, 5, 64220-64227.

[54] J. Sun, W. G. Cheng, Z. F. Yang, J. Q. Wang, T. T. Xu, J. Y. Xin, S. J. Zhang, Green Chem., 2014, 16, 3071-3078.

[55] W. G. Cheng, F. Xu, J. Sun, K. Dong, C. K. Ma, S. J. Zhang, Synth. Commun., 2016, 46, 497-508.

[56] Z. Z. Yang, L. N. He, C. X. Miao, S. Chanfreau, Adv. Synth. Catal,, 2010, 352, 2233-2240.

[57] T. Wang, W. L. Wang, Y. Lyu, X. K. Chen, C. Y. Li, Y. Zhang, X. G. Song, Y. J. Ding, RSC Adv., 2017, 7, 2836-2841.

[58] X. W. Zhang, W. L. Dai, S. F. Yin, S. L. Luo, C. T. Au, Front. Environ. Sci. Eng. Chin., 2009, 3, 32-37.

\title{
固载型季铵盐离子液体催化合成环状碳酸酯：烷基链长及羟基的影响
}

\author{
焉晓明 ${ }^{\mathrm{a}, \mathrm{b}}$ ，丁 璇 $\mathrm{a}$ ，潘 昱 ${ }^{\mathrm{a}}$ ，许小伟 ${ }^{\mathrm{a}}$ ，郝 策 ${ }^{\mathrm{a}}$, 郑文姬 ${ }^{\mathrm{a}}$, 贺高红, ${ }^{\mathrm{a}, \mathrm{b}}$, \\ ${ }^{\mathrm{a}}$ 大连理工大学石油与化学工程学院, 精细化工国家重点实验室, 辽宁盘锦124221 \\ ${ }^{\mathrm{b}}$ 大连理工大学化工学院, 精细化工国家重点实验室, 辽宁大连 116024
}

摘要: $\mathrm{CO}_{2}$ 是造成温室效应的主要原因, 同时又是地球上储量最为丰富的可再生 $\mathrm{C} 1$ 能源. 因此, $\mathrm{CO}_{2}$ 资源化受到了广泛关注. $\mathrm{CO}_{2}$ 与环氧化物反应可合成环状碳酸酯, 后者广泛用作极性溶剂、锂离子电池的电解液和聚碳酸酯中间体等. 但是, 由于 $\mathrm{CO}_{2}$ 的化学情性, 其反应需要高活性的催化剂. 近年来, 碱性金属、金属配合物及离子液体等均相催化剂被用于催化 $\mathrm{CO}_{2}$ 与环氧 化物加成反应. 其中, 离子液体具有高热稳定性、低挥发性和结构可调性, 得到了广泛研究. 季铵盐、咪唑盐和季鏻盐等离 子液体已经被证实具有较高的催化活性. 然而, 均相催化剂回收困难, 而且产物需要进一步纯化. 将离子液体固载化制备成 非均相催化剂, 可以实现简单的固/液分离. 聚合物、 $\mathrm{SiO}_{2} 、 \mathrm{SBA}-15$ 、氧化石墨烯和羧甲基纤维素等固载化催化剂已经广泛 用于 $\mathrm{CO}_{2}$ 和环氧化物的环加成反应. 虽然非均相催化剂显示了潜在的优势, 但是催化活性较低的问题仍然亟待解决, 尤其是 在较温和的反应条件下. 因此,通过催化剂分子结构设计以提高催化性能,成为目前的研究热点.

本文提出在催化活性基团和载体之间引入长烷基链,增加催化活性位点与反应物的接触面积, 同时引入助催化的羟基, 通过长链与羟基的协同作用, 提高非均相催化剂活性. 本文合成了羟基功能化长柔性链季铵化聚苯乙烯微球非均相催化剂 ([AHTAPC-PS]X, $\mathrm{X}=\mathrm{Cl}, \mathrm{Br}, \mathrm{I}$ ), 用于催化 $\mathrm{CO}_{2}$ 与环氧化物的环加成反应, 并与不含羟基的长烷基链季铵盐离子液体非均相 催化剂([TAPB-PS]Br)及短烷基链季铵盐离子液体非均相催化剂([TMA-PS]X)的催化性能进行了对比. 考察了固载后的离 子液体烷基链长及侧链羟基对催化性能的影响, 并通过实验和密度泛函理论计算研究了催化机理. 红外光谱、扫描电镜和 能量散射谱结果充分证明了季铵盐非均相催化剂的成功合成; 热重测试表明, 此类催化剂具有可以满足反应需求的热稳定 性. 密度泛函理论计算结果显示, 与短烷基链非均相催化剂相比, 长烷基链非均相催化剂的阴离子负电性更强, 同时羟基与 环氧化合物的氧原子之间存在强的氢键作用. 羟基形成的氢键可以增加环氧化物的 $\mathrm{C}-\mathrm{O}$ 键长, 同时强负电的阴离子更加容 易攻击 $\beta$-碳原子, 促进环氧化物开环. 另外, 长烷基链结构使得卤素阴离子具有与反应物更大的接触范围, 因此提高了反应 活性. 当采用短烷基链季铵盐非均相催化剂时, 环氧丙烷 $(\mathrm{PO})$ 与 $\mathrm{CO}_{2}$ 环加成反应生成碳酸丙烯酯 $(\mathrm{PC})$ 的产率仅为 $70.9 \%$, 而 采用长烷基链季铵盐非均相催化剂时产率可达 $91.4 \%\left(135^{\circ} \mathrm{C}, 1.5 \mathrm{MPa}, 3 \mathrm{~h}\right)$, 进一步加入助催化的羟基, 则 $\mathrm{PC}$ 产率可提高到 98.5\%. 此外, 含羟基的长烷基季铵盐非均相催化剂在温和条件下也具有较高的催化活性 $\left(100^{\circ} \mathrm{C}, 1.5 \mathrm{MPa}, 3 \mathrm{~h}, \mathrm{PC}\right.$ 产率 $78.4 \%$ ), 该催化剂同时具有较高的循环稳定性(10次循环后, PC产率 $\geq 96 \%$, 选择性 $\geq 99 \%$ ). 综上所述, 该催化剂具有优异的综 合性能, 展现了良好的工业应用前景.

关键词: 环加成反应; 季铵盐; 长烷基链; 羟基; 非均相催化

收稿日期: 2017-02-14. 接受日期: 2017-03-16. 出版日期: 2017-05-05.

*通讯联系人. 电话/传真: (0411)84986219; 电子信箱: hgaohong@dlut.edu.cn

基金来源：国家自然科学基金(21406031, 21476044, U1663223); 长江学者奖励计划(T2012049); 精细化工国家重点实验室 (KF1507); 大连市高层次人才创新支持计划(2015R056); 辽宁省教育厅(LT2015007); 中央高校基本科研业务费专项资金 (DUT16TD19).

本文的英文电子版由Elsevier出版社在ScienceDirect上出版(http://www.sciencedirect.com/science/journal/18722067). 